\title{
Guidelines for sizing roof windows
}

\author{
S. Robertson \& M. Thompson \\ University of East London and the Centre for Alternative Technology, UK
}

\begin{abstract}
Roof windows are often used as a major glazing element in loft conversion projects and to create a room in the roof space of new residential developments. Selecting the correct size of roof window is subject to a range of potentially competing influences, including the need to satisfy building regulations and planning control legislation. This paper describes a recent investigative project to address a particular research question: 'When considering the daylighting and energy consumption aspects, how can designers determine the appropriate size and position for roof windows in loft rooms?' The primary objective was to identify appropriate roof window size and position for a typical loft room, when based on accepted numerical daylighting criteria. The research method that was adopted used standard calculations, scale modelling under an artificial sky, computer simulations and internal illuminance measurements for real loft rooms. The relative daylighting performance of a dormer window was also determined using similar techniques. By considering an example of typical modern residential construction, it was then possible to illustrate the effect of variation in roof window size on annual energy consumption. Finally, the paper outlines the preliminary development of a simple graphical design tool that exploits the research. This tool is intended to assist homeowners and designers in selecting roof windows that optimise both the daylighting and energy consumption aspects.
\end{abstract}

Keywords: roof windows, dormer windows, loft conversions, daylighting, energy consumption, design tools.

\section{Introduction}

Roof windows are tilting double glazed units that are fitted in the plane of the sloping roof surface. Such windows are often used as a major glazing element in conversion projects for domestic lofts, agricultural barns and former industrial 
buildings. Modern construction techniques including structural insulated roof panels and planning trends such as the higher density requirements for new residential developments mean that roof windows are also increasingly used to illuminate rooms within the roof space of new build housing.

Selecting the appropriate size for roof windows is subject to a range of potentially competing influences, including the need to satisfy building regulations and planning control legislation. For instance, the understandable desire for a well daylit interior with consequently low electric lighting load may well conflict with the need to achieve a low average $U$ value and the associated reduction in the annual heating energy requirement.

In relation to the sizing and position of conventional vertical windows, the question of daylighting has been investigated and documented by authors such as Hopkinson et al. [1] and Littlefair [2]. Much of this work on daylighting theory has been embodied in practical guides including the CIBSE Lighting Guide LG10 Daylighting and Window Design [3]. Baker and Steemers [4] have produced material that describes the potential conflict between daylighting and thermal performance requirements and have developed this to provide predictive techniques such as the LT Method.

However, there is little independently published work to provide the same degree of guidance for sizing roof windows. Whilst it is possible to determine optimum roof window size using some of the sophisticated lighting and thermal simulation tools that are now available to designers, this level of effort is unlikely to be appropriate for a typical loft conversion or new build project.

Consequently, for mainstream construction projects it is common practice to refer to the available industry guidance from industry bodies and manufacturers in order to identify design solutions. As far as the leading manufacturer of such windows is concerned, the available guidance on the topic of roof window sizing has historically used a comparatively simple rule of thumb approach [5]. This proposes a minimum glazed area equivalent to $10 \%$ of the floor area in order to achieve adequate natural daylighting levels. It is further suggested that the overall effect is usually improved by increasing this ratio to around $20 \%$ of the floor area. An associated common statement is that a roof window will admit $40 \%$ more light than the equivalent dormer window. This guidance also appears in a number of texts that are aimed at homeowners who may be considering a loft conversion project [6].

Choosing the correct size of roof window is important both for external aesthetic and building performance reasons. Although normally prevented by compliance with Building Regulations limits, extreme instances of incorrect sizing could actually produce loft rooms that are unusable. This might be due either to the creation of a poorly illuminated, stuffy attic or a loft room with such a large area of glazing that it resembles a solar oven in summer and a cold garret in the winter. Selecting the optimum size of roof window can undoubtedly produce light, airy loft rooms so the objective of the research was to increase the frequency of this situation for future design projects. Estimates of the total number of such roof windows that are being installed each year were derived from sources such as manufacturer revenue data [7] and the English House 
Condition Survey [8]. It appears that there are approximately 450,000 roof windows being installed in the UK each year, so any general trend towards inappropriate sizing can reasonably be multiplied by this value to determine the cumulative effect.

Therefore the aim of the research was to answer the question: 'When considering the daylighting and energy consumption aspects, how can designers determine the appropriate size and position for roof windows in loft rooms?'

\section{Objectives}

The primary objective was to identify appropriate roof window size and position for a typical loft room, when based on accepted numerical daylighting criteria. Average daylight factor (ADF) is defined as the ratio of average indoor to outdoor illuminance and is the most commonly used indicator of daylighting within a nominated room. The current British Standard BS8206 [9] specifies required daylighting levels based on $\mathrm{ADF}$ values of between $1 \%$ and $2.5 \%$ subject to the intended use of the room in question. However, it is generally accepted that most people now prefer daylighting levels that are approximately twice those defined in this standard [10]. Therefore, this study considered daylighting levels in the range $2 \%$ to $5 \%$, with an optimum value of $3.5 \%$ at the centre of this ideal range.

The particular case of a loft room was selected since it represents one of the most frequent situations in which such windows are used. It also provided a common test case to which a number of different assessment techniques could be applied. The loft room dimensions that were used were consistent with those published in the guidance notes from the leading manufacturer of roof windows [11]. A physical 1:10 scale room was constructed for comparative investigation and a standard CAD toolset was used to create a software representation of the same loft room. In addition, these dimensions matched those of an available full size loft room. It was therefore possible to use a number of different research tactics to determine these indicators and compare them with real world data. Numerical results and observations associated with these different approaches are considered in the following section.

\section{Research}

\subsection{Calculation}

A proposed calculation method for ADF is described by Littlefair [2] and cited in LG10 [3]. This is a widely accepted single stage technique that is used to calculate ADF from a number of fixed variables. Although this approach is more usually applied to vertical windows, LG10 does show it being applied to sloping glazing and in the absence of any other readily available single stage technique, this method has been used to assess its suitability for sizing roof windows during the loft room design process. This is found using the Littlefair and Plymouth expression: 


$$
\mathrm{ADF}=\mathrm{TA}_{\mathrm{w}} \partial / \mathrm{A}\left(1-\mathrm{R}^{2}\right) \%
$$

where the terms have the following meanings:

$\mathrm{T}$ diffuse transmittance of the glazing

$\mathrm{A}_{\mathrm{w}} \quad$ net area of the window

$\partial \quad$ angle of the visible sky in degrees

A total area of the room surfaces

$\mathrm{R}$ average internal surface reflectance

Based on these calculations, it seems that the predicted ADF for the typical loft room will be approximately $\mathrm{x} 0.35$ the ratio of glazing to floor area. This implies that a roof window of $10 \%$ of the floor area would result in an ADF of $3.5 \%$, which is in the centre of the ideal range.

\subsection{Scale modelling}

Next, a scale room placed under an artificial sky was used to determine the ADF for a number of test cases. The 1:10 scale room had dimensions equivalent to $4.0 \mathrm{~m} \times 2.5 \mathrm{~m}$ internal floor plan and $2.5 \mathrm{~m}$ internal ceiling height with a $45^{\circ}$ pitch. The internal finishes of the scale room were generally identical with those of the full size room and the external surfaces of the scale room were finished in black to represent a typical concrete tile or slate roof surface. As is normal practice for such scale rooms, no glazing was installed and a correction factor was then applied in the analysis. This scale room was placed under an artificial sky, of the mirror box type that replicated overcast sky conditions. Internal illuminance levels were measured using a $0.5 \mathrm{~m}$ scale grid on a working plane at $0.7 \mathrm{~m}$ scale height. The results suggested that with a $2.0 \mathrm{~m}$ head height and a typical room profile, installation of a roof window will result in an average daylight factor (ADF) that is $0.46 \mathrm{x}$ the glazing to floor area ratio. Therefore in a typical loft conversion with a $45^{\circ}$ roof pitch, from the scale modeling it appears that an average daylight factor (ADF) of $3.5 \%$ can be achieved using a roof window with a glazing to floor area ratio of $7.6 \%$.

\subsection{Simulation}

Daylighting simulation tools such as Radiance [12] and FlucsDL [13] can be used to predict daylighting levels and numerical indicators such as ADF. The simulation model was a single loft room with dimensions of $4.0 \mathrm{~m} \times 2.5 \mathrm{~m}$ internal floor plan, $2.5 \mathrm{~m}$ internal ceiling height and a $2.0 \mathrm{~m}$ window head height. All the detailed dimensions of the room were consistent with those of the scale room and with those of the full size loft room. In setting up the simulation, the location and orientation together with all of the internal finishes, glazing type and construction materials were either the default values used within the Radiance and FlucsDL simulation environments or were set to be consistent with those of the scale room. In order to be consistent with the data from the calculation and scale modelling, this daylighting data also used simulated 
overcast sky conditions. The Radiance simulation work suggested that installation of a roof window would result in an ADF that is 0.43 times the ratio of glazing to floor area. Within a reasonable margin of simulation error, the work with FlucsDL generally supported these findings and showed that a roof window will result in an $\mathrm{ADF}$ that is 0.45 times the ratio of glazing to floor area. Therefore, in a typical loft room with a $45^{\circ}$ roof pitch, the simulation work predicted that an ADF of $3.5 \%$ could be achieved using a roof window with a ratio of glazing to floor area of between $8.13 \%$ (Radiance) and $7.78 \%$ (FlucsDL).

\subsection{Measurement}

Comparing these results with measured data from a full size loft room was also possible since all the dimensions and internal finishes were consistent. This loft room also had plan dimensions of $4.0 \mathrm{~m} \times 2.5 \mathrm{~m}$ and a $45^{\circ}$ roof pitch. In this room, the roof window had a glazed area of $0.82 \mathrm{~m}^{2}$ with a head height of $2.0 \mathrm{~m}$. Data was collected for the equivalent grid points as used in the scale room. Based on three sets of data collected, the measured ADF was found to be $4.97 \%$. Applying these findings would imply that in order to achieve an ADF of $3.5 \%$ with a fixed head height of $2.0 \mathrm{~m}$, it would be necessary to install a roof window with a glazing area of $5.83 \%$ of the floor area.

\subsection{Summary}

For the typical loft room that was investigated, the combined calculation, experimental, simulation and measurement data in this study seem to suggest rather lower values for the required glazing area than that which has been identified in the majority of the existing guidance material. The findings are:

$\begin{array}{lll}\text { - } & \text { Method } & \text { ADF:glazing to floor area ratio } \\ \text { - } & \text { Calculation } & 0.35: 1 \\ \text { - } & \text { Scale modelling } & 0.46: 1 \\ \text { - } & \text { Simulation } & 0.43: 1 \text { to } 0.45: 1 \\ \text { - } & \text { Measurement } & 0.60: 1\end{array}$

Averaging these findings and applying equal weighting to each, it appears that a linear relationship of ADF to glazing to floor area ratio of $0.46: 1$ will generally apply. This means that in a typical loft room, a roof window with a glazing area of $7.6 \%$ of the floor area will normally result in an ADF in the region of $3.5 \%$. If the two extreme values based on the calculation and measurement aspects are ignored then an almost identical linear relationship will still apply. This second approach may be justified on the basis of the potential inapplicability of the Littlefair and Plymouth expression to roof windows and the reduced confidence level for the measurement data due to the inevitably limited number of data points associated with one full size loft room. 


\subsection{Comparison with dormer windows}

In visually sensitive situations for historic buildings and conservation areas, it is possible to debate the relative merits of dormer windows as compared with the use of small conservation rooflights. To a degree, any conclusions on this topic are somewhat subjective. However, the internal room qualities can be assessed more objectively. A comparative investigation using the well proven Radiance daylighting simulator has previously been published by Dubois et al. [14]. It indicated a relative ADF for a roof window of approximately 3 times that of a dormer window of equal glazed area, which seems to be at odds with the published guidance from a major roof window manufacturer. The work carried out by the authors generally supported the findings described by Dubois et al. Comparative scale room and simulation data was collected for a dormer window using the same techniques as described above for the roof windows. In particular, the ADF for roof window was found to be 2.9 times that of a dormer window of identical roof aperture size and head height.

\subsection{Energy consumption}

As far as the predicted energy consumption is concerned, the available techniques are rather more limited. Given the project duration, it was impractical to consider collecting data from a real loft room over an extended period. Energy consumption data from scale rooms is generally not considered particularly valuable and in any event it was expected the proportionately small change in energy consumption with changes in roof window area would potentially be masked by experimental error and measurement limitations. The use of the Apache thermal simulator appeared to offer the most promising option for predicting annual energy consumption and was applied to a number of test cases. From this simulation, it was apparent that the range of values for annual energy consumption are much less sensitive to changes in roof window area than is the case for daylighting levels. For the typical example that was analysed, varying the roof window area from zero to $20 \%$ of the floor area resulted in a maximum variation in energy consumption between $1830 \mathrm{kWh}$ and $2330 \mathrm{kWh}$ or $21 \%$ of the maximum value. The minimum total annual energy consumption was with a glazing to floor area ratio of between $13 \%$ and $17 \%$, depending on the orientation of the loft room.

\section{Comparison of tactics}

Calculation of daylighting levels for loft rooms using a single stage method was comparatively rapid but it appears that the usual calculation method will tend to underestimate the daylighting performance of roof windows.

The use of scale rooms under artificial sky conditions provided access to daylighting prediction based on variables that would not routinely be possible in full size rooms. Obvious instances of this flexibility included variation in the window area and the ability to change from a dormer to a roof window at will. 
The collection of data under the artificial sky represented a very stable and repeatable test environment, without the variability of weather conditions. The scale room was intuitive to use and provided good quality data, albeit typically at a resolution that was limited by the scale of model and the precision to which the model had been constructed. The majority of these observations are consistent with those described by Littler [15].

In contrast, the simulation techniques allowed for finer resolution and provided photo realistic rendering data. In order to obtain valid data, it was important to construct a CAD model that accurately reflected the room under investigation. The simulation tools also required care during the setting up phase to ensure that the results reflected reality. The use of a common data model within the IES Virtual Environment was also valuable as it facilitated a comparison of the Radiance and FlucsDL results for the same CAD model.

The measurement activity generally affirmed the qualitative findings from the calculation, scale modelling and simulation work. It also directly related the findings to a real environment and highlighted some of the intrinsic issues in the measurement of lighting levels in a practical context. Although the data set was small, from the measurement work it did seem that in some cases the actual daylighting performance of roof windows might exceed that predicted by scale rooms or using simulation techniques. From a practical point of view, the challenge in the measurement work was one of normalizing the recorded results in order to try and eliminate the effects of any minor variations in aspects such as reflectance and geometry.

\section{Design tool}

A derived objective of the project was the preliminary development of a simple graphical design tool to exploit the research. This tool is intended to assist homeowners and designers in sizing suitable roof windows that optimise both the daylighting and energy consumption aspects. It is based on two graphs that plot the linear change in predicted ADF and the $U$ shaped variation in energy consumption with increasing roof window area. This tool will apply to a reasonably common set of conditions for aspects such as roof pitch, construction type and location.

\section{Conclusions}

This paper makes a case for amending the current guidance on roof window sizing and also the stated relative performance of such windows in comparison with dormer windows. Rather than suggesting $10 \%$ of the floor area as the minimum for adequate daylighting, it appears that for typical loft rooms a roof window sized at $7.6 \%$ of the floor area will actually provide optimum daylighting levels. Roof windows have been confirmed to provide daylighting levels that are approximately three times better than equivalent dormer windows, which may sometimes encourage their preferential selection for visually sensitive situations. Lastly, in the case of specifically low energy designs and 
assuming adequate control mechanisms, roof windows having a glazing area that is between $13 \%$ and $17 \%$ of the floor area may be the most energy efficient solution.

\section{References}

[1] Hopkinson R G, Petherbridge P and Longmore J., Daylighting, Heinemann, London, pp. 59-107, 1966.

[2] Littlefair P J., Site Layout Planning for Daylight and Sunlight: a Guide to Good Practice, Building Research Establishment Report, Watford, 1991.

[3] CIBSE., Lighting Guide LG10 Daylighting and Window Design, Elsevier, Oxford, pp. 15-68, 1999.

[4] Baker N and Steemers K., Energy and Environment in Architecture, Spon, London, pp. 22-25 and pp. 42-52, 2000.

[5] Velux Ltd., Loft Conversion Guide, Velux, Glenrothes, pp. 29-31, 2003.

[6] Hymers P., Home Conversions, New Holland, London, p. 85, 2003.

[7] Velux Ltd., Directors Report and Financial Statements, Velux, Glenrothes, pp. 3-9, 2004.

[8] Office of the Deputy Prime Minister, English House Condition Surveys, 2003 and 2005.

[9] British Standards Institution, BS8206 Part 2 Code of Practice for Daylighting, BSI, London, pp. 2-7, 1992.

[10] Borer P and Harris C., The Whole House Book, Centre for Alternative Technology, Machynlleth, pp. 35-36, 1998.

[11] Velux Ltd., Architects Binder, Velux, Glenrothes, 2005.

[12] Ward Larson G and Shakespeare R., Rendering with Radiance - The Art and Science of Lighting Visualization, Morgan Kaufmann, San Francisco, 1998.

[13] Integrated Environmental Solutions Ltd., Virtual Environment Version 5, Integrated Environmental Solutions, Glasgow, 2003.

[14] Dubois M C, Grau K, Traberg-Borup S and Johnsen K., Impact of Three Window Configurations on Daylight Conditions: Simulations with Radiance. Internal Report, Danish Building and Urban Research, Hørsholm, Denmark, 2003.

[15] Littler J., Test Cells: Do We Need Them? Building and the Environment, volume 28, Pergamon Press, London, p. 222, 1993. 